\title{
Metatropic dysplasia
}

INSERM

\section{Source}

INSERM. (1999). Orphanet: an online rare disease and orphan drug data base. Metatropic dysplasia. ORPHA:2635

Metatropic dysplasia (MTD) is a rare spondyloepimetaphyseal dysplasia characterized by a long trunk and short limbs in infancy followed by severe and progressive kyphoscoliosis causing a reversal in proportions during childhood (short trunk and long limbs) and a final short stature in adulthood. 